\title{
The Impact of State Political Party Association on the Gender Wage Gap
}

\author{
Reginald Wilson \\ The University of Southern Mississippi \\ Audrey Kelly \\ The University of Southern Mississippi
}

\begin{abstract}
This study investigates whether political party association impacts the gender wage gap in the United States of America. This study is motivated by the impact of gender wage gap on females' choice of major, which directly impacts the national economy. Gender wage gap data is collected from 50 states; Mississippi is a proxy for the Republican Party and New York is a proxy for the Democratic Party. The empirical results reveal that political party association is positively and significantly associated with the gender wage gap. This study is the first to document the relationship between gender wage gap and political party association.
\end{abstract}

Keywords: gender wage gap, equal pay, political party association

\section{INTRODUCTION}

The purpose of this study is to investigate whether political party association explains the gender wage gap. ${ }^{1}$ Understanding the potential causes of the gender wage gap is important for a number of reasons. One, the gender wage gap has decreased minimally despite the Equal Pay Act of 1963 (The Act, hereafter), which disallows discrimination in terms of wages to employees solely on the basis of gender (The Equal Pay Act of 1963, 1963). Women make up the majority of the accounting profession; ${ }^{2}$ however, their salaries are approximately twenty-five percent of their male counterparts (Catalyst, 2018). This discrepancy has yet to be explained. The current study seeks to understand whether states' political party association contributes to this gender wage gap.

Two, it is important that students entering their field(s) of study be aware of the gender wage gap prior to entering that field. Wages are an important factor for many individuals, especially recent graduates looking to begin a career. Shedding light on the gender wage gap will not only benefit women who are entering the accounting field, but also women who are beginning their collegiate careers. In order to plan for their living and educational costs, women should be aware of the pay associated with their job prospects prior to choosing a degree and entering the field. In the United States (US), New York (a democratic state) currently has the lowest gender wage gap (tied with California), while Mississippi (a republican state) has the third largest gap (tied with West Virginia) (Mulhere, 2018). This suggests that it is important for female college graduates from universities in republican states and those looking to begin careers in those states to be aware of the gender wage gap in the accounting field. 
Three, understanding the impact of the gender wage gap on the US economy has implications for women's disposable income, which directly affects the national income. New York is a northeastern state that prides itself on giving citizens and noncitizens the chance to attain the American Dream. ${ }^{3}$ The idea of the American Dream is shattered by the doctrine that the gender wage gap is evident, and females are unable to earn equal wages that are comparable to males for the same work, education and experience. Compared to men, the percentage of women's income that is designated as disposable income is smaller due to the gender wage gap, all things being equal. This affects women's purchasing power as well as the national economy. Disposable income has a direct relationship with gross domestic product, thereby affecting the nation's production. ${ }^{4}$ As disposable income increases, consumption increases because individuals have more funds to spend and save in the market economy. In turn, this increase in spending (i.e. consumption) causes a nation's gross domestic product to increase (GDP, hereafter). Therefore, disposable income has a direct relationship with GDP. Eradication of the gender wage gap may result in a higher percentage of disposable income for women, who, if they choose to spend rather than save the income, would improve the national economy. The increase in spending to improve the national economy makes the American Dream more attainable for women, which is what has been the goal since America's founding.

Regression analysis is used to explore the impact of state political party association during the 2016 presidential election year on gender wage gap by state. Mississippi is a proxy for the republican political party and New York is a proxy for the democratic political party. If political party association inversely affects the gender wage gap for both states, one can deduce that this variable impacts the gender wage gap as a whole and can be deemed a significant factor.

Overall, the results reveal that political party association positively affects the gender wage gap. Further analyses suggest that states' political party association with either the Democratic or the Republican Party directly impacts legislation adopted for each state. The results indicate that the democratic legislation supports the adoption of Equal Pay Legislation. If Republican states were to adopt Equal Pay legislation on the state level, this could potentially reduce the gender wage gap.

The remainder of this study is organized as follows. The next section analyzes literature associated with the study and concludes with a set of research questions posed from the existing research. The following section explains the methodology taken and discusses calculations involved. The results of the study are described in the fourth section of the paper, followed by the conclusion and suggestions for future research.

\section{LITERATURE REVIEW}

\section{Gender Pay Nationally}

Nationally, the gender wage gap has been a topic of heavy discussion by US legislators over the past thirty years. The Equal Pay Act of 1963 was one of many legislative efforts that increased the rights of women in the workplace on a national level and paved the way for equality of all genders, ethnicities and races. ${ }^{5}$ The Act prohibits discrimination based on gender for equal work and gives females the opportunity to earn equal salaries for the same jobs and skillsets. ${ }^{6}$ Equality of work is determined based upon the skills required for a specific job and are not specific at the individual level. Legally, the skills required for a position include experience, training, education and ability (Joint Economic Committee, 2009). Since human resource departments account for these factors when determining the equality of work for a job and setting salary schedules, these factors should not contribute to the existence of a gender wage gap, or the gap would be deemed illegal. However, Chairwoman Carolyn B. Maloney of New York explains that there was an eleven percent gender wage gap for federal employees, even after accounting for workers' income level, occupation, age and education (Joint Economic Committee, 2009). Also, the National Partnership for Women and Families ${ }^{7}$ indicates that the national gender wage gap exists despite an individual's education level (National Partnership for Women and Families, 2017). ${ }^{8}$ Thus, it appears that factors explain the presence of the gender wage gap other than education, experience, training and ability. ${ }^{9}$ 
The purpose of this study is to investigate the theory that political party association impacts the gender wage gap. The gender wage gap has decreased significantly since 1980, when the difference in pay was thirty-six percent (Graf et al., 2018). In the 2016 presidential election, New York and twenty-one other states voted alongside the democratic nominee. On Equal Pay Day in 2018, the Democratic Party stated that they were “....proud to champion equal pay for equal work. Democrats believe that women's economic strength is American economic strength, and that is why closing the gender wage gap is an issue we should all be fighting for" (DNC on Equal Pay Day, 2018). Based on this statement, it appears that the Democratic Party aligns strongly with equal pay legislature. Therefore, it is not surprising that states associated with the Democratic Party in the 2016 presidential election maintain lower gender wage gaps. Next, we discuss the legislation associated with the two states that we use as proxies for the political parties.

\section{Gender Pay in New York (Democratic State)}

New York's gender wage gap (approximately eleven percent; Mulhere, 2018; Hill et al., 2018) appears to be much lower than that of the other forty-nine states. In 2013, the New York Assembly (NY Assembly, hereafter) enacted the New York State Fair Pay Act, which makes it illegal for New York employers to pay different wages to individuals for equal work based on gender, race or origin. The results of the floor vote were published, reporting a seventy percent affirmation vote ("A05958 Summary"). Democratic Party representatives widely support equal pay legislation in New York, while the Republican Party representatives reject the proposed legislation ("A05958 Summary"). ${ }^{10}$ These findings reinforce the idea that the impact of political party association on enacted legislation affects equal pay legislation at the state level. In turn, the amount of equal pay legislation by state strongly influences the presence of a gender wage gap. Since citizens of New York associate more closely with the Democratic Party and the majority of the New York Assembly are members of the Democratic Party, it is expected that equal pay legislation would pass within the state.

Following the 2017 (New York State Assembly, 2017) and 2018 (New York Assembly, 2018) National Equal Pay Days, the NY Assembly Speaker, Carl Heastie, released statements regarding the state's progression towards equality in the workplace, which suggests, despite New York having the lowest gender wage gap, "there is still a long way to go," (New York State Assembly, 2018). The statement explains that while it is illegal to discriminate on the basis of gender, pay disparities still exist.

New York's market is the second most lucrative when comparing accountant salaries nationwide, and the state has the largest salaries compared to all other forty-nine states and Washington D.C. (U. S. News, 2017). Even so, specific legislature has not been imposed in New York to improve the gender wage gap among the accounting profession. However, progress has been made in other professions that can be applied to the accounting industry in the state. For example, the Equal Pay for Teachers bill, enacted in New York State in 1925 asserts that no discrimination can be made based upon gender and teachers participating in equal work to his or her counterparts are to be paid equal wages (Pattee, 1925). Catherine Clifford reports that special education teachers have a four percent gender wage gap compared to accountants who have a seven percent gender wage gap (Clifford, 2018). It is conceivable that legislation similar to the Equal Pay for Teachers Bill will provide support for the reduction of the wage gap in all professions in each of the fifty states.

\section{Gender Pay in Mississippi (Republican State)}

Mississippi, a predominately Republican state, is one of only two states that does not have equal pay legislation (Fowler, 2018). ${ }^{11}$ Mississippi is tied for the largest gender wage gap, reporting at twenty-seven percent (Mulhere, 2018). In April of 2016, the Republican National Committee made the statement, "Republicans believe we must focus on real solutions geared toward job creation and opportunity for women. . ." (RNC Statement, 2016). However, when the Senate made a motion to vote on the Paycheck Fairness Act in $1914^{12}$, no Republican senators voted in support of the bill. These votes were consistent with those of Republicans in New York. 
In February of 2018, a proposed equal pay bill was denied in a state senate hearing. Unlike the Democratic Party representatives in New York State, however, Democratic equal pay supporters voted to veto the bill in Mississippi, claiming that the legislation was not a true equal pay bill which left room for wage discrimination (Fowler, 2018). ${ }^{13}$

Gender pay in Mississippi has become a topic of recent discussion as a result of the 2018 senate race. On November 27, 2018, Mississippi elected Republican Cindy Hyde-Smith to the Senate. Since the state began pushing for equal pay reform, there have been two attempts to secure this legislation (in 2017 and 2018); both attempts were declined by the state supreme court to create an equal pay act at the state level (Fowler, 2018). Mississippi's inability to reform its legislature in support of equal pay could be a factor that contributes to its high gender wage gap. Compared to New York, however, additional legislation providing more strict controls and regulations on public employers aides in the furtherance of equal pay and provides women with more opportunities to gain equality in the workplace. The following research question examines whether an association with the Democratic Party or the Republican Party significantly affects gender wage gap, as follows:

RQ1: Using proxies for democratic states (New York) and republican parties (Mississippi), do states' political party association significantly impact the gender wage gap?

\section{METHODOLOGY}

\section{Dependent Variable}

The dependent variable in this study is the gender wage gap. The gender wage gap for each respective state was collected from an online source, TIME magazine (Mulhere, 2018). The gender wage gap is calculated by incorporating the salary and gender data into a simple equation. The unadjusted gender wage gap represents the simplest calculation for gender pay. It does not consider the factors that contribute to gender pay in different disciplines; however, it is useful when determining a general difference and will be the equation used for the purpose of this study.

Glassdoor determined that a new equation can be used to include factors that may impact the gender wage gap. This equation is referred to as the "adjusted" gender wage gap. Glassdoor explains, "In addition to gender, this comparison will ensure we've accounted for differences in education, experience, type of job role and other factors that differ between men and women. The goal is to make a fair comparison between similar workers, to see what gender wage gap remains" (Chamberlain, 2017). For the purpose of this study, calculations were made using the unadjusted gender wage gap.

\section{Independent Variable}

In this study, the independent variable of interest is the political party association by state. The political party association was collected from The New York Times (New York Times, 2017), after the results were announced from the November 8, 2016 election. The proxy for democratic states is New York and the proxy for Republican states is Mississippi.

\section{Regression Analysis}

Regression analysis was conducted to examine the relationship between the reported gender wage gap and the political party association for each state for the most recent presidential election year (2016). The regression analysis included the political party association for each state during the 2016 presidential election (independent variable) and the gender wage gap (dependent variable). If the two variables are positively correlated, then the legislation posed by the leading party of the state will presumably impact the presence of the gender wage gap. 


\section{RESULTS}

\section{Descriptive Statistics}

Table 1 provides descriptive statistics for the variables that were researched during the course of this study. The results demonstrate that the majority of states in America associate with Republican Party (29) while less of the population of states associate with the Democratic Party (22). The states associating with the Democratic Party have an average gender wage gap of approximately eighteen percent $(18 \%)$, compared to that of the republican associated states whose gender wage gap is approximately twenty-two percent $(22 \%)$. These statistics suggest that democratic states are more likely to adopt legislation that supports equal pay and reduces the gender wage gap than republican states, an assertion that is supported by Illustration 1, which displays the floor vote results of the New York Fair Pay Act.

TABLE 1

DESCRIPTIVE STATISTICS

\begin{tabular}{|l|c|c|}
\hline & Democratic Party & Republican Party \\
\hline Number of States & 22 & 29 \\
\hline $\begin{array}{l}\text { Average Earnings per } \\
\text { Dollar }\end{array}$ & 0.8182 & 0.7739 \\
\hline $\begin{array}{l}\text { Average Gender Wage } \\
\text { Gap }\end{array}$ & 0.1818 & 0.2241 \\
\hline
\end{tabular}

\section{FIGURE 1 \\ VOTING DISTRIBUTION AS RELATING TO POLITICAL PARTY ASSOCIATION}

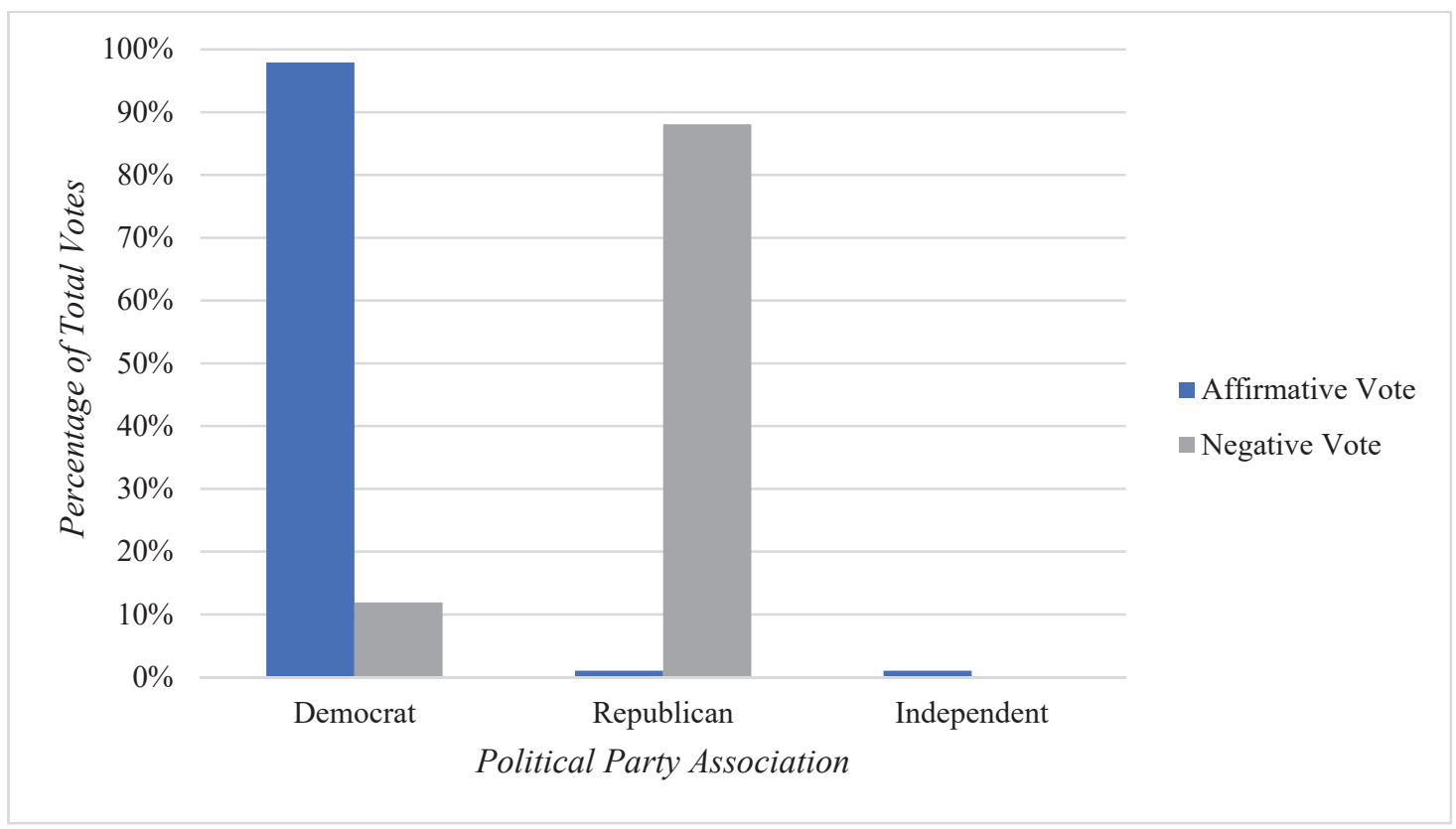

\section{Preliminary Analysis}

A correlation analysis was used to determine the degree of correlation between the political party association (independent variable) and the gender wage gap (dependent variable). After looking at the correlation analysis, the gender wage gap, represented as earnings per dollar, is averagely correlated with 
political party association (Table 2). This suggests that the two variables can be analyzed together in the research and that no variables should be eliminated from the data. Next, we conduct a regression analysis.

TABLE 2

CORRELATION ANALYSIS

\begin{tabular}{|l|c|c|}
\hline & Political Party & Earnings per Dollar \\
\hline Political Party & 1 & \\
\hline Earnings per Dollar & 0.4845 & \\
\hline
\end{tabular}

We conducted a regression analysis comparing the gender wage gap in terms of earnings per dollar (dependent variable) per state and the political party association (independent variable) by state for the 2016 presidential election. The results indicate that the political party association variable does not necessarily yield a strong relationship with the gender wage gap by state, as evidenced by the R-square value in Table 3 (R-squared $=0.2348$ ). Although the gender wage gap is not fully determined by the political party association, the R-Square value reveals a relationship; therefore, the gender wage gap by state can be explained, in part, by the political party association. These results suggest that political party association is not necessarily the sole factor responsible for the presence of the gender wage gap. The Significance F-value is less than 0.0500 (Table 4) suggests that the results of the regression are reliable in determining the relationship between the two variables.

TABLE 3

\section{REGRESSION STATISTICS}

\begin{tabular}{|l|c|}
\hline Observations & 51 \\
\hline Multiple R & 0.4845 \\
\hline R-Square & 0.2348 \\
\hline Adjusted R Square & 0.2191 \\
\hline Standard Error & 0.0386 \\
\hline
\end{tabular}

TABLE 4

REGRESSION ANALYSIS

\begin{tabular}{|l|c|c|c|c|c|}
\hline & Df & SS & MS & F & Significance F \\
\hline Regression & 1 & 0.0224 & 0.0224 & 15.0324 & $0.0003^{*}$ \\
\hline Residual & 49 & 0.0730 & 0.0015 & & \\
\hline Total & 50 & 0.954 & & & \\
\hline
\end{tabular}

$*$ F-Value is significant at $\mathrm{p}<0.05$

Note: Variables with a correlation between 0.0000 and 0.2000 are considered to have low correlation. Variables with a correlation between 0.8000 and 1.0000 are considered to be highly correlated.

Perhaps the most important analysis conducted is the analysis of the regression equation. The resulting regression equation is $y=0.0423 x+0.7759$. This equation suggests the following: as the political party association becomes more closely aligned with the Democratic Party, earnings per share increases by approximately 0.0423 . A similar analysis was run for each of the states. Based upon the analysis for the political party association by state for the 2016 presidential election, the predicted gender wage gap for Mississippi (a republican state) is 0.0459 higher than the actual reported gender wage gap of 0.7300 . The predicted gender wage gap for New York (a democratic state) is 0.0718 lower than the actual reported gender wage gap of 0.8900 . 


\section{Summary of the Analysis for Research Question 1}

The results of the regression analysis support the claim that political party association by state affects the respective gender wage gap of that state. Table 2 reports that political party association has a relationship with the gender wage gap and the Significance F-value reports that the analysis is reliable in determining the relationship. These findings support the assertion that states' political party association impacts the gender wage gap in that state. As analyzed previously, political party association directly impacts the adoption of equal pay legislation within a state. As shown in Illustration 1, Democratic legislators are more likely to support equal pay legislation, while Republican legislators are more likely to veto such legislation. The political party association of elected legislators within a state directly impacts what legislation will be passed in the state Senate and House of Representatives.

\section{CONCLUSIONS AND IMPLICATIONS}

In 1963, the Equal Pay Act was enacted in order to increase equality in the workplace for males and females in respect to wages. This study researches the gender wage gap and in New York and Mississippi to determine where states' political party association impacts the gender wage gap. We find that the effects of political party association through legislation on the gender wage gap relative to two statesMississippi (a Republican State) and New York (a Democratic State)—were determined to be significant. These findings are inconsistent with the purpose of the Equal Pay Act of 1963, which was meant to eliminate the gender wage gap in the US and establish equal rights on the basis of pay for females.

With Mississippi being one of two states without equal pay legislature at the state level, we suggest a solution to lowering the high state gender wage gap would be to draft and pass statewide legislature. New York, the state with the lowest gender wage gap, currently and continuously makes numerous strives to improve and reduce the gender wage gap, through the adoption of legislation. There were four bills introduced in 2018 to continue the equal pay movement, including a bill that would remove the inequality of job titles. This particular legislation will reduce the impact that job title differences have on the gender wage gap. A second proposition will require public employers to submit a report that details wage disparities within their respective companies. A governmental organization will examine the results of the submitted reports to determine where disparities exist, to what extent and what accounts for the differences (New York State Assembly, 2018). Mississippi, however, currently has not made such progress, with each attempt being shut down in state courts.

This exploratory study opens the door for a number of future research opportunities. Future research may seek to further examine the impact of this research on the gender wage gap in other republican states. It is suggested that public education is necessary for Mississippi to pass a state equal pay bill and many democratic leaders are calling for the public's help (Fowler, 2018). It is not clear why Mississippi republicans are reluctant to show support for equal pay at the state level, but many claim that the bills presented are too similar to the federal law and enacting such a bill would do "nothing," (Fowler, 2018). Mississippi legislators and citizens continue to fight for equal pay at the state level. On February 12, 2018, representatives rallied in Jackson, MS to fight for equal pay for Mississippi women (Powell, 2018). Members of the state continue to make strides toward adopting equal pay legislation at the state level. It is a movement that the citizens support and continue to fight for.

When conducting this study, there was limited access to data regarding gender wage gaps for specific industries by state. There was qualitative information reporting that some industries have higher or lower gaps; however, the quantitative data was not available. The data needed to conduct a more in-depth research project is currently not available to the public. The accumulation of such data opens the door for more thorough analysis of the phenomenon that was analyzed in this study.

However, similar methodology can be used to further this research to determine how political party association and education affects the gender wage gap in specific industries. This study provides a basis for reducing the gender wage gap and can be used to expand the solutions to gender wage gaps in other professions. While females hold the majority of the accounting profession's workforce, a gender wage gap still exists at all levels. This pattern that was determined by this study can be furthered to include data 
from specific states. Finding a relationship between political party association and the gender wage gap creates an avenue for change through legislation that has not previously been explored.

\section{ENDNOTES}

1. The gender pay, or wage, gap is the difference between the "average pay for men as a group and the average pay for women as a group," (Chamberlain, 2017). Mathematically, it is calculated by taking the difference in the average male pay and the average female pay and dividing the answer by the average male pay (Chamberlain, 2017). This shows the relationship between the two gender's salaries. The gender wage gap is important to establish whether or not there is a significant discrepancy between the wages of male and female accountants.

2. This paper defines an accountant according to Robert Half, which states an accountant as one who is "responsible for managing and reporting financial information for an organization," (Robert Half, 2018).

3. The American Dream is a term coined in 1931 by James Adams. The American Dream in 1931 was not focused on material items. Adams (1931) suggests that "It is not a dream of motor cars and high wages merely, but a dream of a social order in which each man and each woman shall be able to attain to the fullest stature of which they are innately capable, and recognized by others for what they are." Adams' (1931) original idea involved the understanding that men will be given equal opportunities "according to his ability or achievement." Approximately twenty-three years later, Peter Marshall redefined the American Dream, saying that the idea is now "Religious liberty to worship God according to the dictates of one's own conscience and equal opportunity for all men" (Lam, 2017). Today, the American Dream is less about one's personal freedoms and principles and more about material goods (Lam, 2017).

4. Disposable income is a term representative of the amount of money one has left over after taxes are taken out of one's paycheck (Williams, 2019). Gross Domestic Product, or GDP, is the total value of products produced within a country during a specified period of time. This value is calculated by summing consumption, investments, government spending and net exports (Amadeo, 2019). While this simple equation does not directly reflect disposable income, consumption is directly related to disposable income. As disposable income increases, consumption increases.

5. The acts promoting equal pay include: The Healthy Families Act, The Family and Medical Insurance Leave Act (FAMILY Act), The Paycheck Fairness Act, The Raise the Wages Act and The Lily Ledbetter Fair Pay Act of 2009.

6. The Mississippi Bar explains that equal work under the law is defined as a job that requires "equal skill, effort and responsibility and are performed in similar working conditions" (The Mississippi Bar, 2019).

7. The National Partnership for Women and Families is a nonprofit organization devoted to promoting fairness in the workplace and developing policies that will benefit women and their families (National Partnership for Women and Families, 2018).

8. Research finds that full-time female employees with a master's education are paid eighty-two percent of their male counterparts' wages with equal education (National Partnership for Women and Families, 2017).

9. Race, experience, education, age and occupation have been found to determine an exact gender wage gap in an industry, company or within a group of individuals (Chamberlain, 2017). In a study conducted in 2014, human-capital resources, sociodemographic characteristics, working hours and occupation each attribute to the gender wage gap (Mandel et al., 2014). While these factors may attribute to the gender wage gap, as Congresswoman Maloney pointed out, the gap exists beyond demographic and education factors such as these. Furthermore, in an article published by Washington College of Law, women have an unexplained difference in earnings compared to "equally situated men" (Tufarolo, 2016). This means that full-time female employees with an equal position, after having accounted for all potential sociodemographic and educational factors, are earning proportionately less for the same position. Tufarolo states, "this evidence proves that even between equally qualified and educated men and women, men continue to earn more than their female counterparts in most fields." The comparison of education level achieved to gender and, furthermore, to lifelong earnings provides evidence that females earn significantly different wages in multiple fields. Women working in fields where the females make up the majority of the population of employees are female are still earning a significantly lower difference than their male counterparts (Kim et al., 2015).

10. Of the 97 affirmative voting assembly members, 95 members are Democratic Party affiliates. Of the 42 negative voting assembly members, 37 members associated with the Republican Party. 
11. On May 26, 2019, the city capital in Jackson, MS (the capital city) unanimously passed an equal pay ordinance (Victory, 2019).

12. The Paycheck Fairness Act would make it "illegal for employers to retaliate against workers who inquire about or disclose their wages or the wages of other employees in a complaint or investigation. It also would make employers subject to civil actions by employees who feel aggrieved" (Lowrey, 2014).

13. With the republican party historically vetoing equal pay legislation, it is surprising that, Lynn Fitch, Mississippi State Treasurer and republican party affiliate, supported an equal pay legislation presented by the democratic representatives of the state in 2017, but the bill died in committee and never received public support (Fowler, 2018).

\section{REFERENCES}

A05958 Summary. (n.d.). Retrieved January 6, 2019, from $\mathrm{https}: / /$ nyassembly.gov/leg/?default_fld=\&leg_video=\&bn=A05958\&term=2013\&Summary=Y\& Floor Votes $=\mathrm{Y} \& \mathrm{Text}=\mathrm{Y}$

Adams, J. T. (1931). The Epic of America. Boston: Little, Brown and Co.

Amadeo, K. (2019, January 17). Gross Domestic Product: Understanding What a Country Produces. Retrieved February 6, 2019, from https://www.thebalance.com/what-is-gdp-definition-of-grossdomestic-product-3306038

Catalyst. (2018). Catalyst, Quick Take: Women in Accounting. Retrieved from https://www.catalyst.org/knowledge/women-accounting

Chamberlain, A. (2017). How to Analyze Your Gender Pay Gap: An Employer's Guide. Glassdoor Economic Research. Retrieved May 8, 2018, from https://www.glassdoor.com/research/studies/how-to-analyze-gender-pay-gap-employers-guide/

Clifford, C. (2018). These 10 jobs have the largest and smallest pay gaps between men and women. Retrieved October 31, 2018, from https://www.cnbc.com/2018/04/09/the-10-jobs-with-thelargest-and-smallest-gender-pay-gaps.html

DNC on Equal Pay Day. (2018). Retrieved October 31, 2018, from https://democrats.org/press/dnc-onequal-pay-day/

The Equal Pay Act of 1963. (1963). Retrieved August 28, 2018, from https://www.eeoc.gov/laws/statutes/epa.cfm

Fowler, S. (2018). Equal pay efforts dead in Legislature. Retrieved October 31, 2018, from https:/www.clarionledger.com/story/news/2018/02/28/equal-pay-efforts-deadlegislature/380669002/

Fowler, S. (2018). Will an equal pay bill ever pass in Mississippi? Retrieved January 18, 2019, from https://www.clarionledger.com/story/news/local/2018/01/21/equal-pay-bill-ever-passmississippi/1035903001/

Graf, N., Brown, A., \& Patten, E. (2018). The narrowing, but persistent, gender gap in pay. Retrieved August 28, 2018, from http://www.pewresearch.org/fact-tank/2018/04/09/gender-pay-gap-facts/

Hill, C., Miller, K., Benson, K., Maatz, L., Nielson, K. J.D., \& Bibler, K. (2018). The Simple Truth About the Gender Pay Gap. Washington DC: AAUW.

Joint Economic Committee. (2009). Equal Pay for Equal Work? New Evidence on the Persistence of the Gender Pay Gap. Retrieved November 30, 2018, from https://www.gpo.gov/fdsys/pkg/ CHRG-111 shrg52911/pdf/CHRG-111shrg52911.pdf

Kim, C., Tamborini, C. R., \& Sakamoto, A. (2015). Field of Study in College and Lifetime Earnings in the United States. Sociology of Education, 88(4), 320-339.

Lam, K. (2017). The Transformation of the 'American Dream". Retrieved October 31, 2018, from https://www.nytimes.com/2017/08/04/upshot/the-transformation-of-the-american-dream.html

Lowery, W. (2014). Senate Republicans reject equal pay bill. Retrieved October 31, 2018, from

https://www.washingtonpost.com/politics/senate-republicans-reject-equal-pay-

bill/2014/04/09/ce011342-c003-11e3-b574-

f8748871856a_story.html?noredirect $=$ on\&utm_term $=$. a8c9bc7c9939 
Mandel, H., \& Semyonov, M. (2014). Demography, 51, 1597. Retrieved October 27, 2018, from https://doi-org.lynx.lib.usm.edu/10.1007/s13524-014-0320-y

Mulhere, K. (2018). Equal Pay Day: Here Is the Gender Pay Gap in Every State | Money. Retrieved October 30, 2018, from http://time.com/money/5233753/gender-pay-gap-every-state/

National Partnership for Women and Families. (2017). Mississippi Women and the Wage Gap. Retrieved October 30, 2018, from http://www.nationalpartnership.org/research-library/workplacefairness/fair-pay/4-2017-ms-wage-gap.pdf

National Partnership for Women and Families. (2018). About Us. Retrieved November 30, 2018, from http://www.nationalpartnership.org/about-us/

New York State Assembly. (2017). Assembly Passes Legislation to Close the Pay Gap [Press Release]. Retrieved January 6, 2019, from https://nyassembly.gov/Press/20170404/

New York State Assembly. (2018). Assembly Passes Legislation to Close the Pay Gap in New York State, to Ensure Women Receive Equal Pay for Equal Work [Press Release]. Retrieved January 6, 2019, from https://nyassembly.gov/Press/files/20180417.php

New York Times. (2017). Presidential Election Results: Donald J. Trump Wins. Retrieved October 30, 2018, from https://www.nytimes.com/elections/2016/results/president

Pattee, E. N. (1925). The effect of the Equal Pay for Teachers Bill in New York State. Journal of Chemical Education, 2(6), 493.

Powell, S. (2019). Group rallies for equal pay for women. Retrieved February 24, 2019, from https://www.wapt.com/article/women-activist-groups-to-meet-at-state-capitol/26302838

RNC Statement on Equal Pay Day. (2016). Retrieved October 31, 2018, from https://www.gop.com/rncstatement-on-equal-pay-day/

Robert Half. (2018). Accountant job description guide. Retrieved October 30, 2018, from https://www.roberthalf.com.au/our-services/finance-accounting/accountant-jobs

The Mississippi Bar. (2019). Retrieved January 21, 2019, from https://www.msbar.org/for-thepublic/consumer-information/what-is-equal-pay/

Tufarolo, M. A. (2016). You Haven't Come a Long Way, Baby: The Courts' Inability to Eliminate the Gender Gap Fifty-Two Years After the Passage of the Equal Pay Act. Journal of Gender, Social Policy \& the Law, 24(2), 5. Retrieved November 29, 2018, from http://digitalcommons.wcl.american.edu/jgspl/vol24/iss2/5

U. S. News. (2017). How Much Can an Accountant Expect to Get Paid? Retrieved January 21, 2019, from https://money.usnews.com/careers/best-jobs/accountant/salary

Victory, J. (2019). Jackson passes equal pay law. Will it change anything? Retrieved August 3, 2019, from https:/www.clarionledger.com/story/news/politics/2019/05/16/equal-pay-law-city-workersjackson-mississippi-no-salary-history-asked-wage-gap/3678238002/

Williams, G. (2019). How to Determine Your Disposable Income. Retrieved February 6, 2019, from https://money.usnews.com/money/personal-finance/spending/articles/how-to-determine-yourdisposable-income 